Araştırma Makalesi (Research Article)

\section{Onur CAN 1}

Yasemin Senem KUKUL KURTTAŞ2

Emrah ÖZÇAKAL²

\footnotetext{
${ }^{1}$ Kocaeli University, Arslanbey Vocational School, 41285 Kocaeli/Türkiye

${ }^{2}$ Ege University, Faculty of Agriculture, Department of Farm Structures and Irrigation, 35100 izmir/Türkiye e-posta:onur.can@kocaeli.edu.tr
}

Key Words:

Evapotranspiration, Satsuma Mandarin, Salinity, Neutron Probe

Anahtar Sözcükler:

Evapotranspirasyon, Satsuma Mandarini, Tuzluluk, Nötronmetre

\section{The Effect of Salinity in Irrigation Water on Evapotranspiration of Satsuma Mandarin (Citrus unshiu Marc.)}

\author{
Satsuma Mandarininde (Citrus unshiu Marc.) Sulama Suyu \\ Tuzluluğunun Bitki Su Tüketimi Üzerine Etkisi
}

Alınış (Received): 28.01.2014 Kabul tarihi (Accepted): 10.09.2014

\begin{abstract}
his study was carried out for 2 years in order to determine the effect of saline water on the evapotranspiration from Satsuma mandarin trees. In the study, three different salinity levels of irrigation water were applied (S0: 0.65 $\mathrm{dS} / \mathrm{m}$. S1: $3.5 \mathrm{dS} / \mathrm{m}$. S2: $6.5 \mathrm{dS} / \mathrm{m}$ ). Satsuma mandarin trees grafted on Troyer citrange and Poncirus trifoliata rootstocks were used as experimental material. Evapotranspiration was measured by neutron probe in 4 different soil layers ( 0 $30 \mathrm{~cm}, 30-60 \mathrm{~cm}, 60-90 \mathrm{~cm}, 90-120 \mathrm{~cm}$ ) before and after irrigation for six trees in total. The results obtained from the experiment were as follows: (i) evapotranspiration from the Satsuma mandarin trees decreased due to the increase of irrigation water salinity level and (ii) in all subjects, evapotranspiration of the mandarin trees grafted on Poncirus trifoliate rootstock was higher than that of the mandarin trees grafted on Troyer citrange rootstock. The response to salt water of the mandarin trees grafted on Troyer citrange rootstock was higher than that of the mandarin trees grafted on Poncirus trifoliate rootstock.
\end{abstract}

\section{ÖZET}

Ru araştırma, tuzlu suyun Satsuma Mandarini bitki su tüketimi üzerine etkisini belirlemek amacıyla, iki yıl boyunca yürütülmüştür. Araştırmada 3 farklı tuzluluk seviyesine sahip sulama suyu uygulanmıştır (S0: $0.65 \mathrm{dS} / \mathrm{m}$. S1: $3.5 \mathrm{dS} / \mathrm{m}$. S2: $6.5 \mathrm{dS} / \mathrm{m}$ ). Poncirus trifoliata ve Troyer citrange anaçları üzerine aşılı Satsuma Mandarini ağaçları deneme materyali olarak kullanılmıştır. Bitki su tüketimi ölçümleri, nötronmetre kullanılarak sulamadan önce ve sonra dört farklı toprak katmanında yapılmıştı $(0-30 \mathrm{~cm}, 30-60 \mathrm{~cm}, 60-90 \mathrm{~cm}, 90-120 \mathrm{~cm})$. Araştırmadan elde edilen veriler şu şekildedir : (i) Satsuma Mandarini bitki su tüketimi, sulama suyunun tuzluluk seviyesindeki artışa bağlı olarak azalmıştır. (ii) Araştırmada kullanılan Poncirus trifoliata anacı üzerine aşılı mandarin ağaçları, Troyer citrange anacı üzerine aşılı mandarin ağaçlarına göre tüm konularda daha fazla bitki su tüketimi gerçekleştirmiştir. Troyer citrange anacı üzerine aşılı mandarin ağaçlarının tuzlu suya olan tepkisi, Poncirus trifoliata anacı üzerine aşılı mandarin ağaçlarına göre daha fazla gerçekleşmiştir.

\section{INTRODUCTION}

In the past 10 years, mandarin production in the world has increased by $19 \%$ and reached 26.030 .014 tons. Spain, People's Republic of China, Japan, Brazil, and Turkey are the leading mandarin producers of the world. Following Spain and People's Republic of
China, Turkey is the third in mandarin export. In the mandarin export realized in 2011, Spain, People's Republic of China, and Turkey have a share of 34\%, $16 \%$, and $10 \%$, respectively (FAO, 2011). According to the records of the Turkish Export Promotion Center, the leading type of mandarin exported by Turkey in 
2002 is Satsuma mandarin by $54.22 \%$ (AEA, 2002). In 2012, 29.88\% of the Satsuma mandarin production was performed in the Aegean Region (TUIK, 2012).

Of all commercially produced citrus fruits, mandarin comes first in terms of resisting to low temperatures. In the Aegean Region, the most commonly planted rootstocks are Poncirus trifoliata and Troyer citrange. These rootstocks' resistance to low temperatures is higher. So, mandarin is very suitable for the climate conditions of the Aegean Region. Its earliness makes mandarin increase in value in both domestic and foreign markets. For this reason, in many parts of the Aegean Region, especially in Izmir, mandarin is intensively produced. In İzmir leading mandarin producing districts are Menderes and Seferihisar (Can, 2004).

In the process from the production to the export of mandarin, which plays a crucial role in the fruit export of Turkey, salinity is one of the major problems encountered. It is reported by many researchers that one of the most serious problems in relation to groundwater quality is rapid salinization of natural water resources (FAO, 1992; Bear et al. 1999). The increase in the salinity level of groundwater, especially in coastal regions, may result from the influx of natural saline water, such as sea water intrusion, the dissolution of soluble salts in the unsaturated zone, and the flow of saline water from adjacent aquifers (Kass et al., 2005). In Menderes and Seferihisar districts of İzmir, as a result of uncontrolled and excessive draw of underground water for both tourism and agricultural purposes, sea water influxes into coastal aquifers, and consequently groundwater salinity increases.

The use of such water for irrigating the mandarin orchards located in the Aegean Region, where approximately 100.000 tons of mandarins are produced, negatively affects plants and the soil. The increasing level of salinity in irrigation water and soil becomes a significant factor affecting plant development and yield as it makes the intake of water and nutrients difficult for the plant.

Citrus fruits are among the most-produced horticultural crops of the world and relatively sensitive to salt. Salt damage usually consists of leaf burn and defoliation and is associated with the accumulation at toxic levels of $\mathrm{Na}^{+}$or $\mathrm{Cl}^{-}$in leaf cells (Storey and Walker, 1999). In general, citrus growth is hindered if soil saturation extract exceeds $1.4 \mathrm{dS} / \mathrm{m}$. Salt damage increases under low moisture conditions and regular irrigation with water having moderate salt content (for instance, $1.3 \mathrm{dS} / \mathrm{m}$ ) (Davies and Albrigo, 1994).

For Yang et al. (2002), a great majority of the studies in literature were conducted for the purpose of determining the effect of saline water applications on fruit size, quantity and quality, and yield rather than determining evapotranspiration (ET) from citrus fruits. On the other hand, in spite of many researches on the evapotranspiration from citrus trees irrigated with high-quality water, there is not adequate information about the effect of salinity on ET. In their study, Yang et al. (2002) found that irrigation with saline water tended to reduce ET. The mean ET in the saline water application $(8.6 \mathrm{dS} / \mathrm{m})$ was $71 \%$ of the control application $(1.0 \mathrm{dS} / \mathrm{m})$. The reason was reduced transpiration $(\mathrm{T})$ from trees due to salinity.

Yang et al. (2003), in their study, analyzed the evapotranspiration released by the citrus trees irrigated with saline water. In the study, two lysimeters were used for the citrus trees planted under greenhouse conditions. Of the said two lysimeters, one was filled with saline water $(3.8 \mathrm{dS} / \mathrm{m})$ while the other was filled with fresh water. The test results proved reduced evapotranspiration from the citrus trees irrigated with saline water. The evapotranspiration from the trees irrigated with saline water was found to be $60 \%$ of the evapotranspiration from the trees irrigated with fresh water.

This study aimed at investigating the evapotranspiration values obtained as a result of irrigating Satsuma mandarin, which plays a significant role in Turkey's citrus export, with irrigation water having different levels of salinity.

\section{MATERIALS and METHODS}

This study was conducted in the Satsuma mandarin (Citrus unshiu Marc.) study plot created in 1996 in the experimental field of Ege University, Faculty of Agriculture, Department of Horticulture. The experimental field is located on latitude $38^{\circ} 27^{\prime} \mathrm{N}$ and longitude $27^{\circ} 13^{\prime} \mathrm{E}$, with an average altitude of 27 meters. Having been designed in randomized blocks, the experiment consisted of 3 trees per subplot by subject (Figure 1). The experimental material of the study, which was carried out between the years of 2005 and 2006, was the Satsuma mandarin trees grafted on Troyer citrange and Poncirus trifoliata rootstocks. Since 1996, irrigation water having three different levels of salinity (S0: $0.65 \mathrm{dS} / \mathrm{m} \mathrm{S1:} 3.5 \mathrm{dS} / \mathrm{m}$ S2: $6.5 \mathrm{dS} / \mathrm{m}$ ) had been applied to the experimental material. 


\begin{tabular}{|c|c|c|c|c|c|c|c|}
\hline \multicolumn{4}{|c|}{ Trifoliata orange } & \multicolumn{4}{|c|}{ Troyer citrange } \\
\hline SO & S2 & S1 & S1 (*) & S2 (*) & S1 & S2 & S1 \\
\hline S1 & S1 & S2 & SO(*) & SO(*) & S2 & So & S2 \\
\hline S2 & So & So & S2 $\left(^{*}\right)$ & S1 $(*)$ & So & S1 & So \\
\hline
\end{tabular}

(*)Subplots used in the research

Figure 1. Schematic drawing of the Satsuma mandarin study lot (S0: $0.65 \mathrm{dS} / \mathrm{m} . \mathrm{S} 1: 3.5 \mathrm{dS} / \mathrm{m} . \mathrm{S} 2: 6.5 \mathrm{dS} / \mathrm{m})$

In the experiment, a drip irrigation system was employed to apply irrigation water at different salinity levels (S0: $0.65 \mathrm{dS} / \mathrm{m} \mathrm{S1:} 3.5 \mathrm{dS} / \mathrm{m} \mathrm{S2:} 6.5 \mathrm{dS} / \mathrm{m}$ ) and potassium fertilizer ( $300 \mathrm{gr}$./tree $\mathrm{K}_{2} \mathrm{O}$ ) in compliance with farmer's conditions to the trees by triple emitter source technique. In accordance with this technique, the first lateral carried the fresh water with low salt content of the deep well located in the experimental field, the second one carried the saline stock solution $(9.5 \mathrm{dS} / \mathrm{m})$ prepared in the saline water tank, and the third one carried the irrigation water to which potassium fertilizer had been added. Different salinity doses were regulated by the number of drippers placed onto the laterals carrying fresh and saline water. In total, there were 6 drippers per tree on all three laterals. Having a flow rate of $2,3 \mathrm{lt} / \mathrm{hrs}$, the drippers used in the system were equipped with pressure regulators and inserted on the lateral.

Some physical and chemical properties of the study plot soil are given in Table 1.

Table 1. Physical and chemical properties of the study plot

\begin{tabular}{|c|c|c|c|}
\hline $\mathbf{p H}$ & $\mathbf{C a C O}_{\mathbf{3}} \mathbf{( \% )}$ & Texture & EC $_{\mathrm{e}}\left(\mathbf{d S} . \mathbf{m}^{-\mathbf{1}}\right)$ \\
\hline 7.35 & 1.16 & Sandy & 550 \\
\hline Layer Depth $(\mathbf{c m})$ & Field Capacity $\left(\mathbf{c m}^{\mathbf{3}} / \mathbf{c m}^{\mathbf{3}}\right)$ & Wilting Point $\left(\mathbf{c m}^{\mathbf{3}} / \mathbf{c m}^{\mathbf{3}}\right)$ & Bulk Density $\left(\mathbf{g} / \mathbf{c m}^{\mathbf{3}}\right)$ \\
\hline $\mathbf{0 - 3 0}$ & 21.12 & 10.51 & 1.45 \\
\hline $\mathbf{3 0 - 6 0}$ & 25.02 & 12.42 & 1.57 \\
\hline $\mathbf{6 0 - 9 0}$ & 22.05 & 10.70 & 1.60 \\
\hline $\mathbf{9 0 - 1 2 0}$ & 19.86 & 9.61 & 1.53 \\
\hline
\end{tabular}

\section{Soil Moisture Measurements}

In the study plot, 6 trees were picked out of the Satsuma mandarin trees grafted on different rootstocks (Poncirus trifoliata and Troyer citrange), to which irrigation water having 3 different levels of salinity (S0: $0.65 \mathrm{dS} / \mathrm{m} \mathrm{S1:} 3.5 \mathrm{dS} / \mathrm{m} \mathrm{S2:} 6.5 \mathrm{dS} / \mathrm{m}$ ) were applied. For each tree, soil moisture change along the profile was determined. A neutron probe was used in order to determine moisture changes at layers of 30 $\mathrm{cm}(0-30 \mathrm{~cm}, 30-60 \mathrm{~cm}, 60-90 \mathrm{~cm}, 90-120 \mathrm{~cm})$ along the profile. The neutron probe employed in the research was 503 Hydroprobe manufactured by Campell Pasific Nuclear Corp. Next to the trees picked for experiment, aluminum neutron probe measurement tubes were placed $40 \mathrm{~cm}$ away from the stems. For the purpose of determining soil moisture change, soil moisture content was measured by the neutron probe before and after irrigation. Irrigation was applied in the afternoon twice a week, on Monday and Thursday.

In order to find out whether or not there was any moisture action due to capillary rise into the root from lower soil layers, within $20 \mathrm{~cm}$ of each tree, 2 tensiometers were put into the soil depths of $45 \mathrm{~cm}$ and $90 \mathrm{~cm}$. The tensiometer readings before and after irrigation as well as the soil moisture tensions in the above-mentioned depths were measured in millibars (mb).

\section{Determining the Evapotranspiration}

A water budget method was employed to calculate the amount of evapotranspiration from the Satsuma mandarin trees, to which different salinity levels of irrigation water were applied, taking $120 \mathrm{~cm}$ soil depth into consideration (Kutilek and Nielsen, 1994; Fares and Alva, 2000; Kanber and Steduto, 1999).

$$
\mathrm{ET}=\mathrm{I}+\mathrm{Y}+\mathrm{K}-\mathrm{D} \pm \Delta \mathrm{S}
$$

where;
ET: Evapotranspiration (mm);
I: Irrigation water ( $\mathrm{mm})$,
Y: Precipitation $(\mathrm{mm})$,
$\mathrm{K}$ : Capillary rise $(\mathrm{mm})$,
D: Drain water $(\mathrm{mm})$, and

$\Delta \mathrm{S}$ : Change in soil water content ( $\mathrm{mm})$.

\section{Determining the Amount of Irrigation Water}

Before each irrigation, the amount of water to be applied was determined by reading the evapotranspiration value of the previous day from the 
U.S. Class A evaporation pan. The method employed here is the FAO-24 Pan Evaporation (Kanber and Steduto, 1999). In the experimental field, the pan was placed on a wooden platform at a height of $15 \mathrm{~cm}$ from the soil surface.

The relation between reference evapotranspiration $\left(\mathrm{ET}_{\mathrm{o}}\right)$ and pan evaporation is shown by the belowgiven equation.

$$
\mathrm{ET}_{\mathrm{o}}=\mathrm{K}_{\mathrm{p}} \times \mathrm{E}_{\mathrm{p}}
$$

where;

$$
\begin{aligned}
& E T_{\circ} \text { : Reference evapotranspiration ( } \mathrm{mm} / \text { day), } \\
& \mathrm{K}_{\mathrm{p}} \text { : Pan Coefficient, and } \\
& E_{\mathrm{p}} \text { : Pan evapotranspiration ( } \mathrm{mm} / \text { day). }
\end{aligned}
$$

Actual evapotranspiration can be found by multiplying calculated reference evapotranspiration with crop coefficient, which is a function of plant species and plant development stage.

$E T=K_{c} \times E T_{0}$

where;

ET : Actual evapotranspiration ( $\mathrm{mm} /$ day),

$$
\mathrm{K}_{c} \text { : Crop coefficient, }
$$
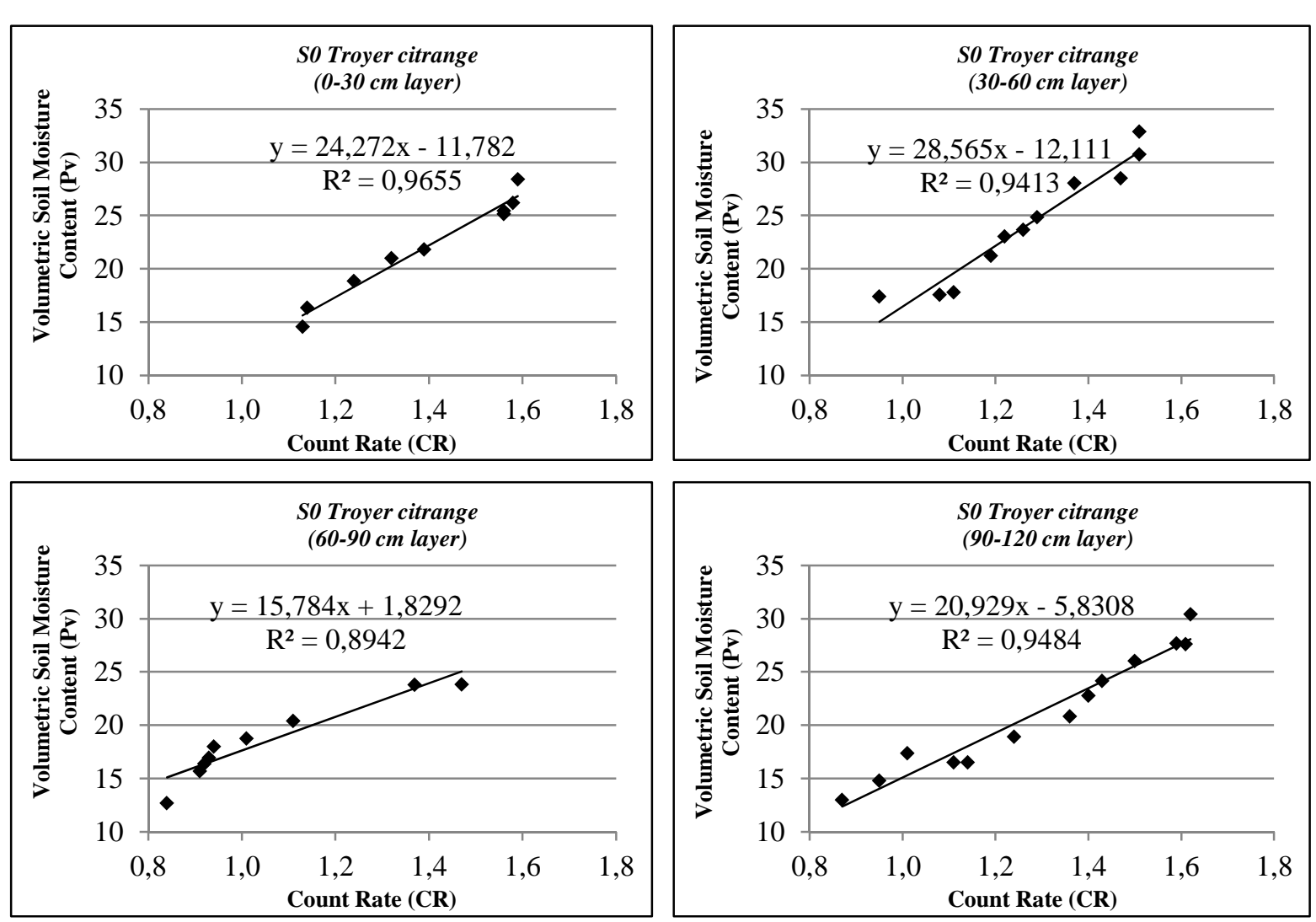

Figure 2. Neutron Probe Calibration Curves by Layers (S0 Troyer citrange)
$\mathrm{ET}_{0}$ : Reference evapotranspiration ( $\mathrm{mm} /$ day).

In this case, if both of the equations are combined:

$\mathrm{ET}=\mathrm{K}_{\mathrm{c}} \times \mathrm{K}_{\mathrm{p}} \times \mathrm{E}_{\mathrm{p}}$

In the research, the multiplication of crop coefficient and pan coefficient $\left(\mathrm{K}_{\mathrm{c}} \times \mathrm{K}_{\mathrm{p}}\right)$ was accepted to be 0,6 . By means of reading the evapotranspiration value of the previous day from the evaporation pan and multiplying it with the said coefficient, the amount of water to be applied was found.

\section{Neutron Probe Calibration}

In the research, the neutron probe was calibrated separately for each of the 6 Satsuma mandarin trees selected to address salinity and rootstock issues. Due to the fact that the soil of the experimental field was alluvial and considerably differed by depth and location, the neutron probe was calibrated on-site for each tree. For calibration, soil moisture values were found gravimetrically in the soil depths of $0-30 \mathrm{~cm}, 30$ $60 \mathrm{~cm}, 60-90 \mathrm{~cm}$, and $90-120 \mathrm{~cm}$ and associated with neutron probe count rates (CR). Figures $2,3,4,5,6$, and 7 demonstrate the Neutron Probe Calibration Curves by Layers. 

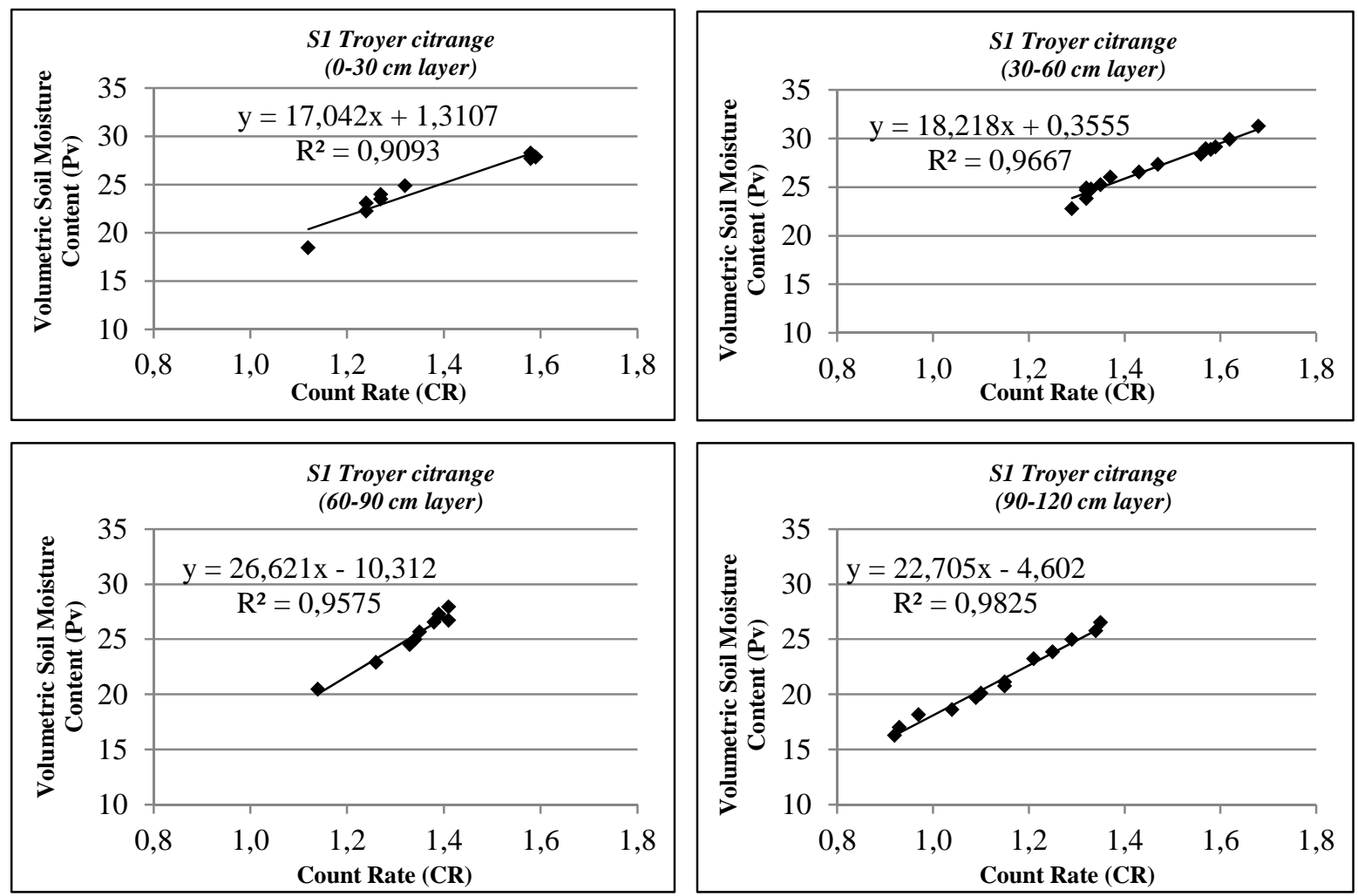

Figure 3. Neutron Probe Calibration Curves by Layers (S1 Troyer citrange)
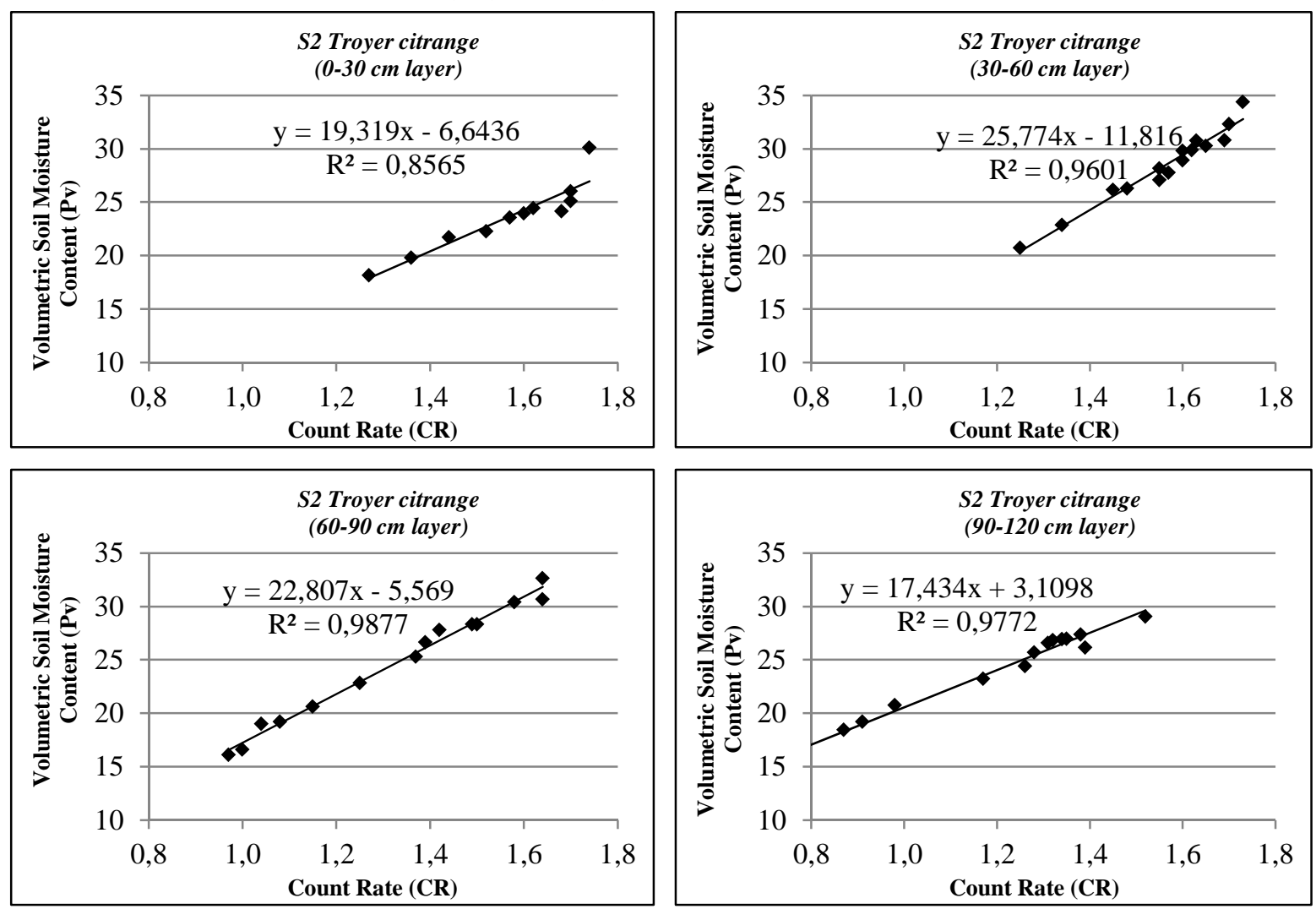

Figure 4. Neutron Probe Calibration Curves by Layers (S2 Troyer citrange) 

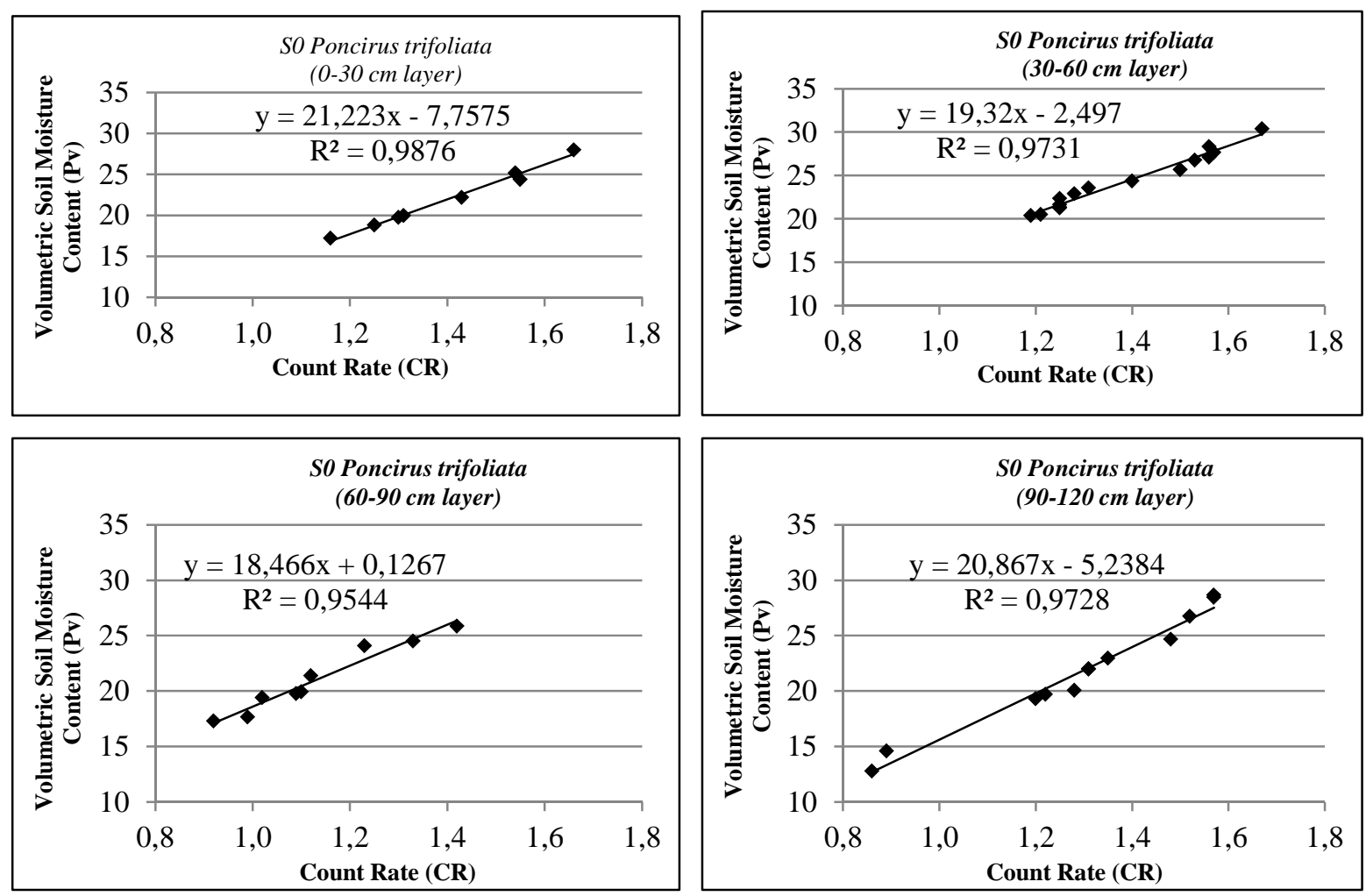

Figure 5. Neutron Probe Calibration Curves by Layers (SO Poncirus trifoliata)
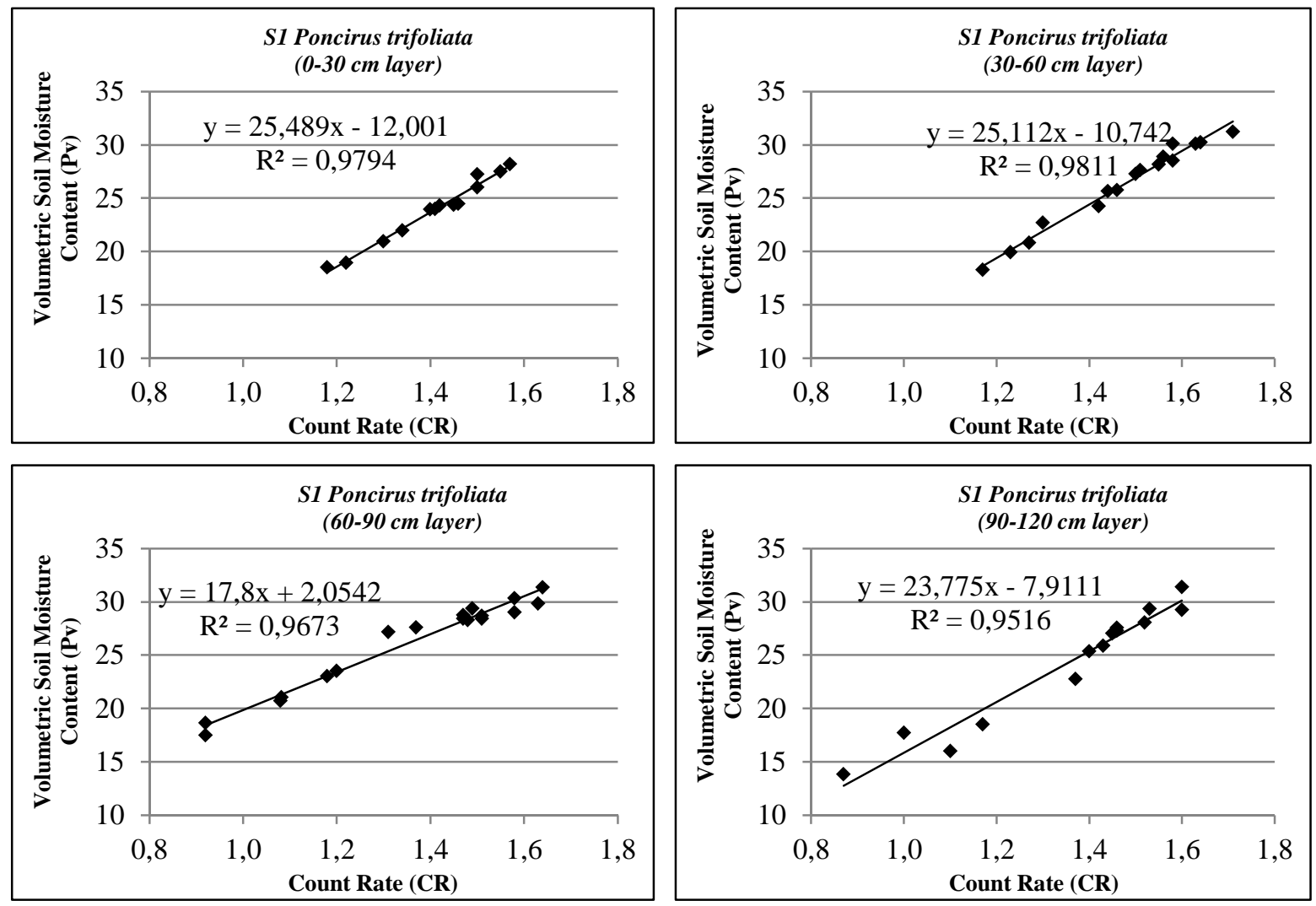

Figure 6. Neutron Probe Calibration Curves by Layers (S1 Poncirus trifoliata) 

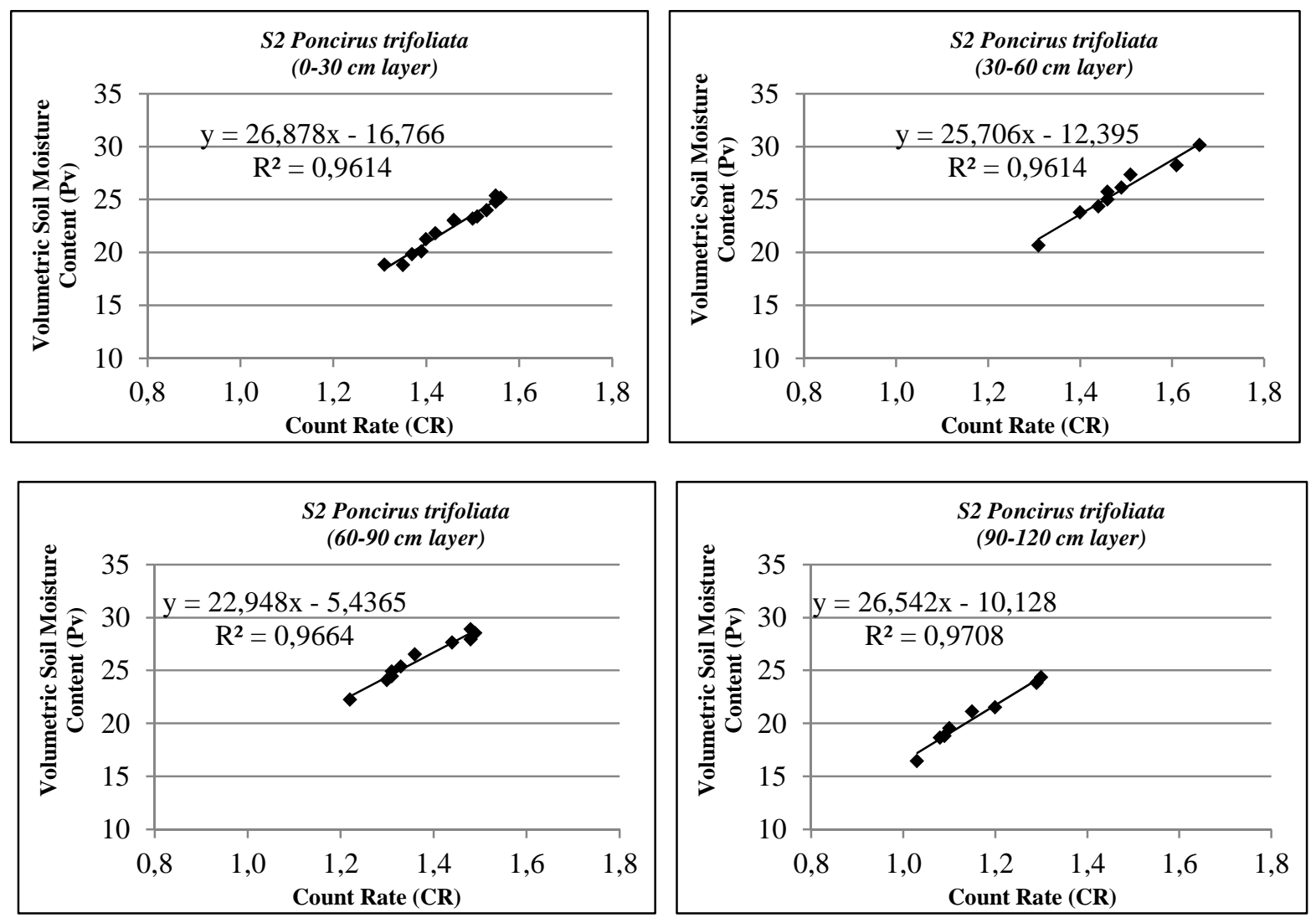

Figure 7. Neutron Probe Calibration Curves by Layers (S2 Poncirus trifoliata)

\section{Irrigation}

In the experimental field, drip irrigation started on July 2005 and ended on November 2005. On the other hand, in 2006, it started again on July but ended on October. During the irrigation period, the trees were irrigated in the amounts ranging from $9.36 \mathrm{~mm}$ to $63.30 \mathrm{~mm}$, and 34 and 32 irrigation applications were performed in 2005 and 2006, respectively. In each irrigation, the amount of water was determined using the U.S. Class A evaporation pan. For this reason, irrigation water amounts differed as a function of climatic factors. In 2006, depending on the growth of trees, crown projection area was enlarged 2.5 folds, and consequently the seasonal irrigation amount increased relatively.

\section{RESULTS}

\section{Seasonal Evapotranspiration (ET)}

Figures 8 and 9 show the seasonal (JulyNovember) evapotranspiration values by subject obtained in 2005 and 2006. Given both of the seasonal evapotranspiration values, it can be seen that the highest evapotranspiration values were in S0, which had the lowest level of salinity $(0.65 \mathrm{dS} / \mathrm{m})$, while the lowest evapotranspiration values were in S2, which had the highest level of salinity $(6.5 \mathrm{dS} / \mathrm{m})$. As for $\mathrm{S} 1$, which had a medium level of salinity $(3.5 \mathrm{dS} / \mathrm{m})$, evapotranspiration values were found to be between the highest and the lowest levels. The evapotranspiration values of the trees, to which three different doses of salinity were applied, decreased depending on the dose. Under control conditions, decrease in evapotranspiration for Poncirus trifoliata was $4.06 \%$ in S1 and $12.01 \%$ in S2 in 2005 while $15.15 \%$ in $\mathrm{S} 1$ and $39.64 \%$ in S2 in 2006. On the other hand, under control conditions, decrease in evapotranspiration for Troyer citrange was $22.81 \%$ in S1 and $25.83 \%$ in S2 in 2005 while $36.16 \%$ in S1 and $36.38 \%$ in S2 in 2006. If the effect of rootstock difference on evapotranspiration is analyzed, it is seen that the evapotranspiration values of the trees grafted on Poncirus trifoliata rootstock decreased considerably when the dose of salinity was $6.5 \mathrm{dS} / \mathrm{m}$. However, a significant decrease was observed in the evapotranspiration values of the trees grafted on Troyer citrange rootstock when the dose of salinity was $3.5 \mathrm{dS} / \mathrm{m}$. 


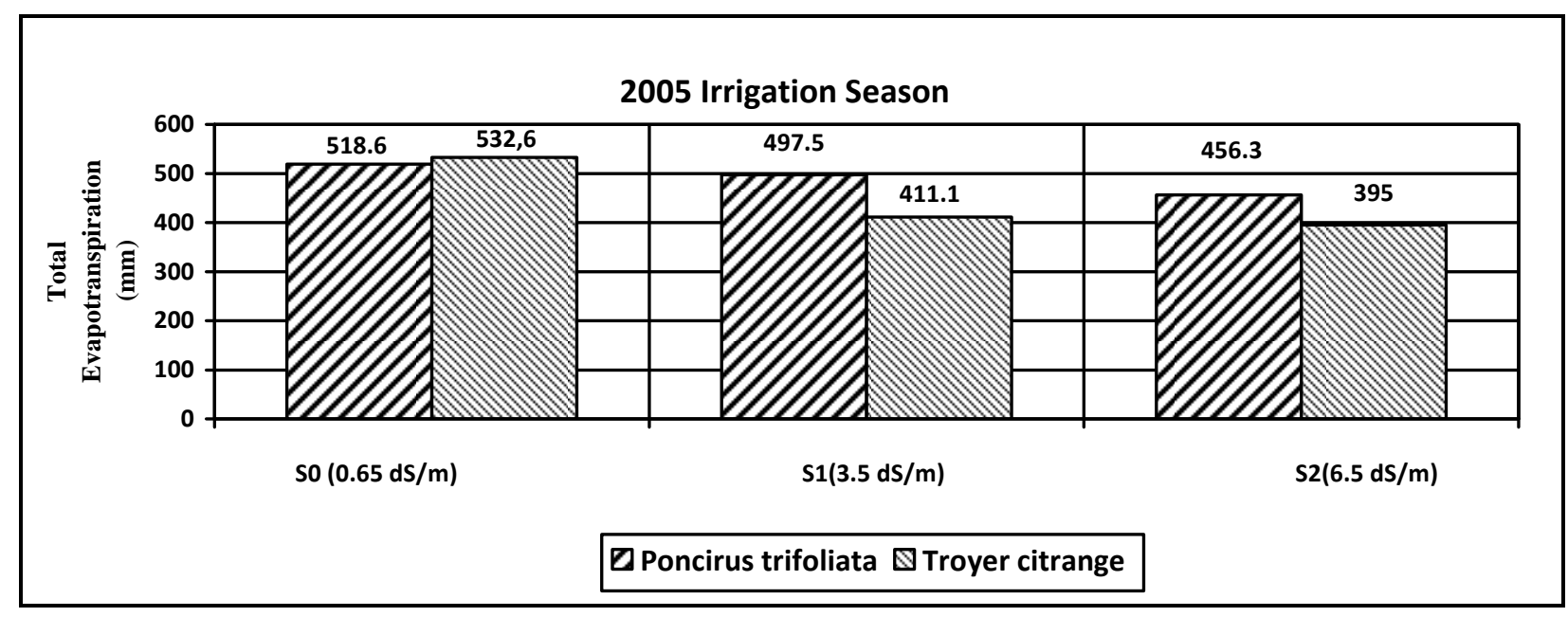

Figure 8. Evapotranspiration between July 1 and November 16, 2005 (139 days)

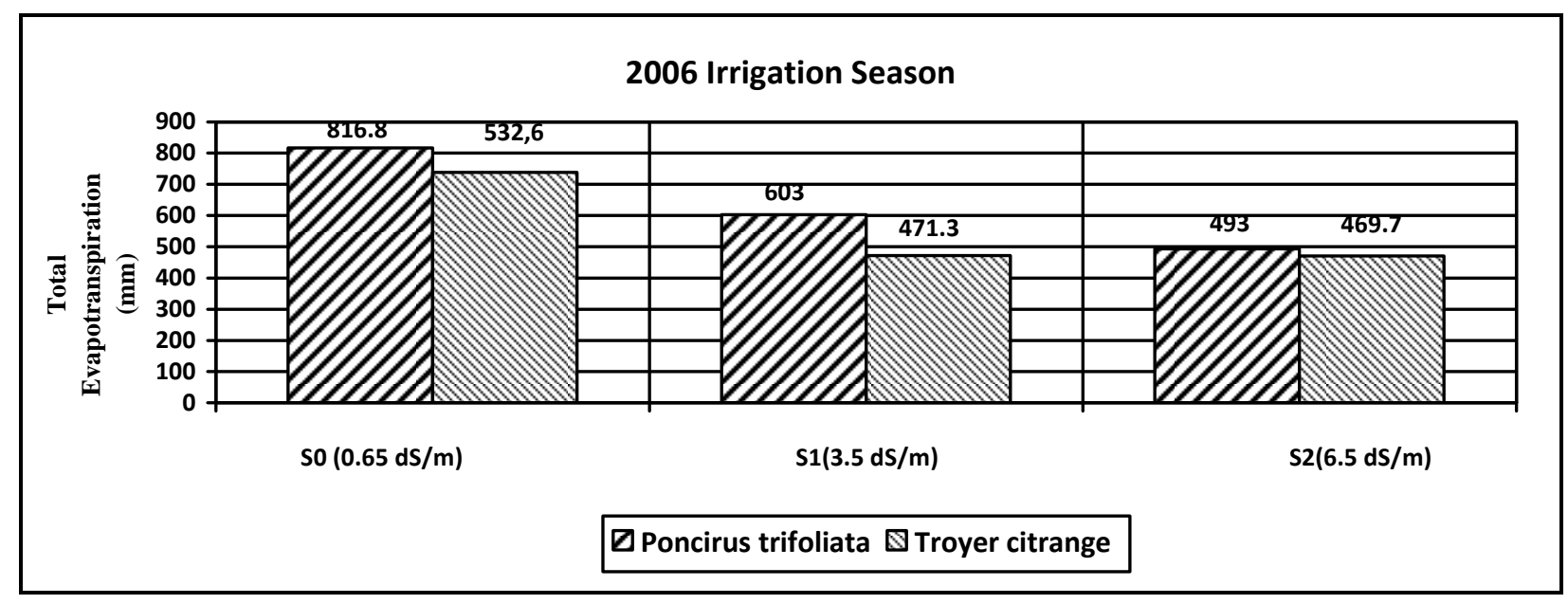

Figure 9. Evapotranspiration between July 1 and October 30, 2006 (123 days)

Depending on the salinity of irrigation water, evapotranspiration rate or decrease coefficient designates the decrease in evapotranspiration (Yang et al. 2003). $\mathrm{ET}_{\text {saline water }}=\mathrm{Ks} \times \mathrm{ET}_{\text {fresh water }}$. Figures 10 and 11 demonstrate the evapotranspiration rates of the Satsuma mandarin trees grafted on Troyer citrange and Poncirus trifoliata rootstocks. According to the data obtained, the evapotranspiration rate of the mandarin trees grafted on Poncirus trifoliata rootstock was higher at a lower level of salinity $(3.5 \mathrm{dS} / \mathrm{m})$ but decreased at a higher level of salinity $(6,5 \mathrm{dS} / \mathrm{m})$. But the evapotranspiration rate of the mandarin trees grafted on Troyer citrange rootstock was similar at both lower and higher levels of salinity. From the above-given results, it can be deducted that the mandarin trees grafted on Poncirus trifoliata rootstock continue to evapotranspirate even at a lower level of salinity.

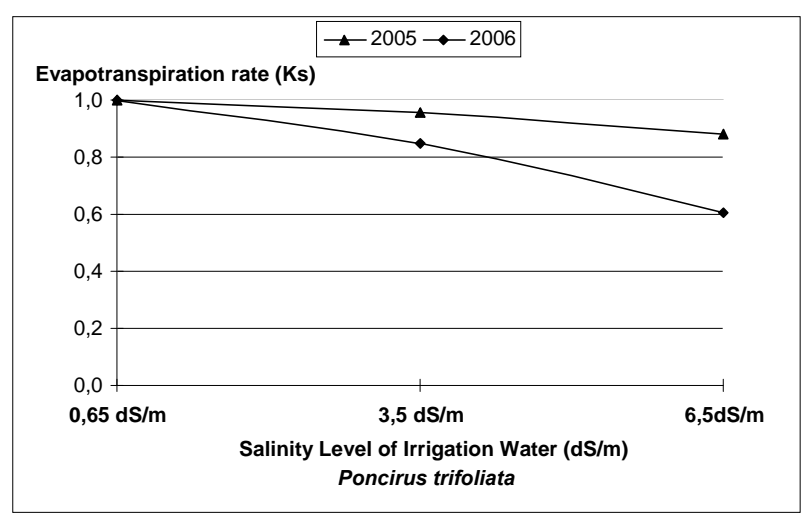

Figure 10. Evapotranspiration rate of the Satsuma mandarin trees grafted on Poncirus trifoliata rootstock 


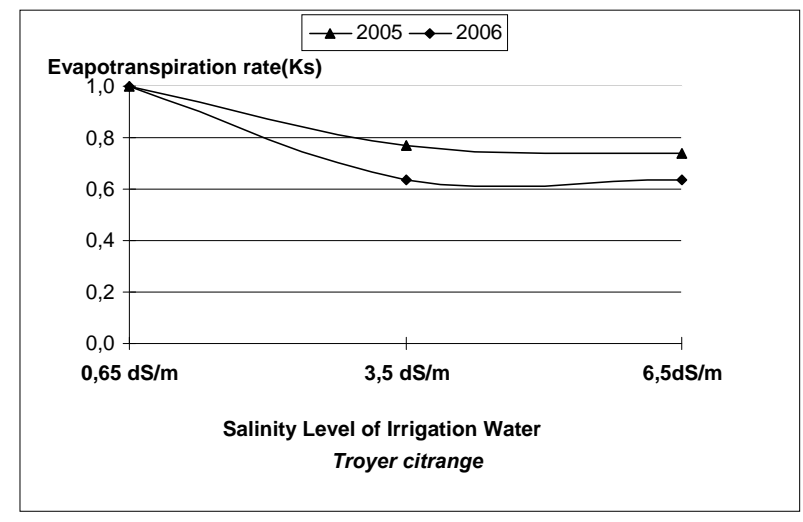

Figure 11. Evapotranspiration rate of the Satsuma mandarin trees grafted on Troyer citrange rootstock

\section{Daily Evapotranspiration}

Considering the daily evapotranspiration values acquired from the subjects, the highest daily evapotranspiration values were observed in July for 2005 but in August for 2006. Towards the end of the experiment, a significant decrease occurred. Figure 12 and 13 demonstrate the mean daily evapotranspiration rates by month of the Satsuma mandarin trees grafted on Troyer citrange and Poncirus trifoliata rootstocks for different levels of salinity. According to the data obtained, daily evapotranspiration rates decreased depending on the proportional increase in irrigation water salinity. The data of 2006 were found to be higher due to the increase in the amount of irrigation water applied.
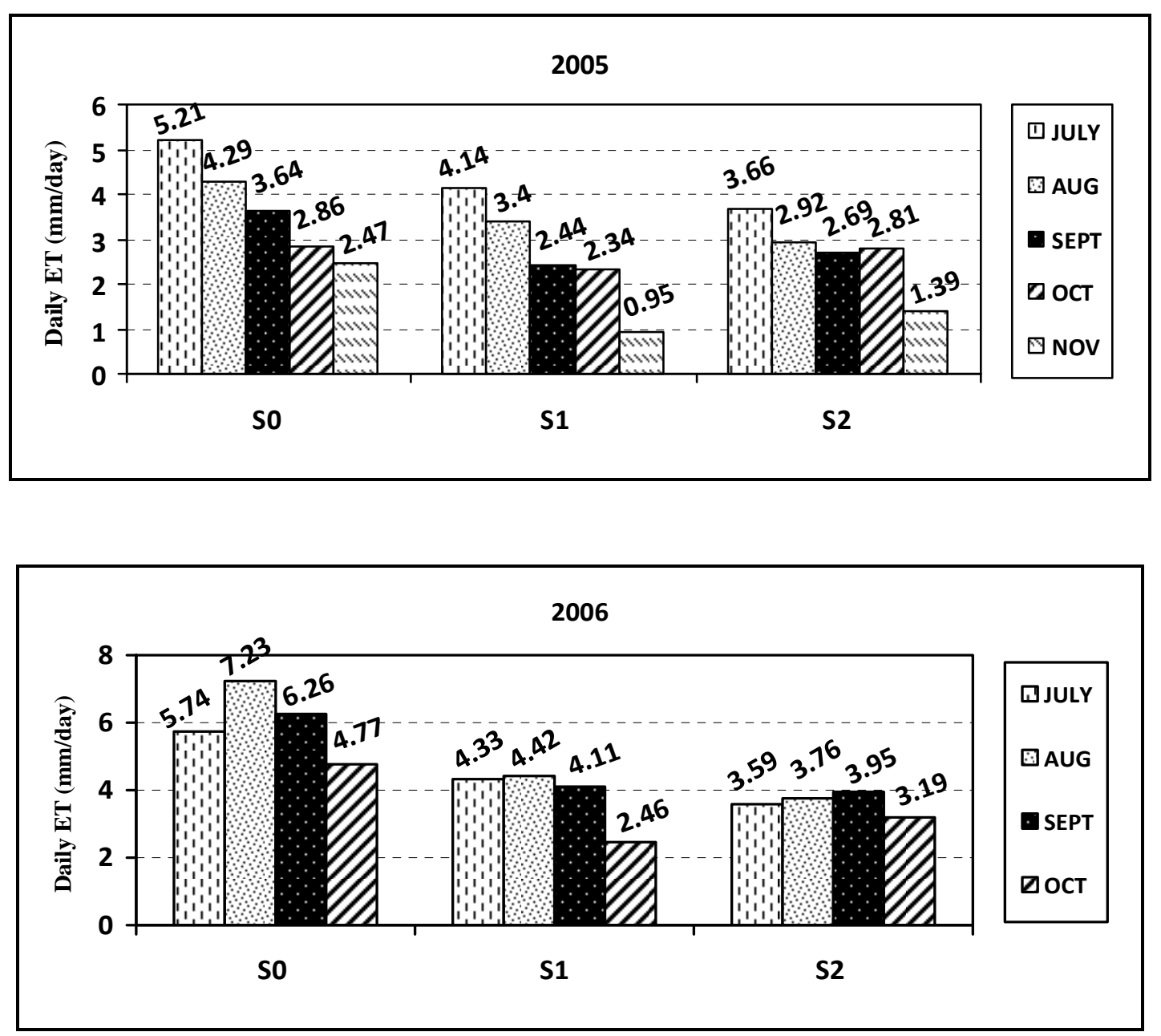

Figure 12. Mean daily ET values ( $\mathrm{mm} /$ day) by month of the Satsuma mandarin trees grafted on Troyer citrange rootstock 

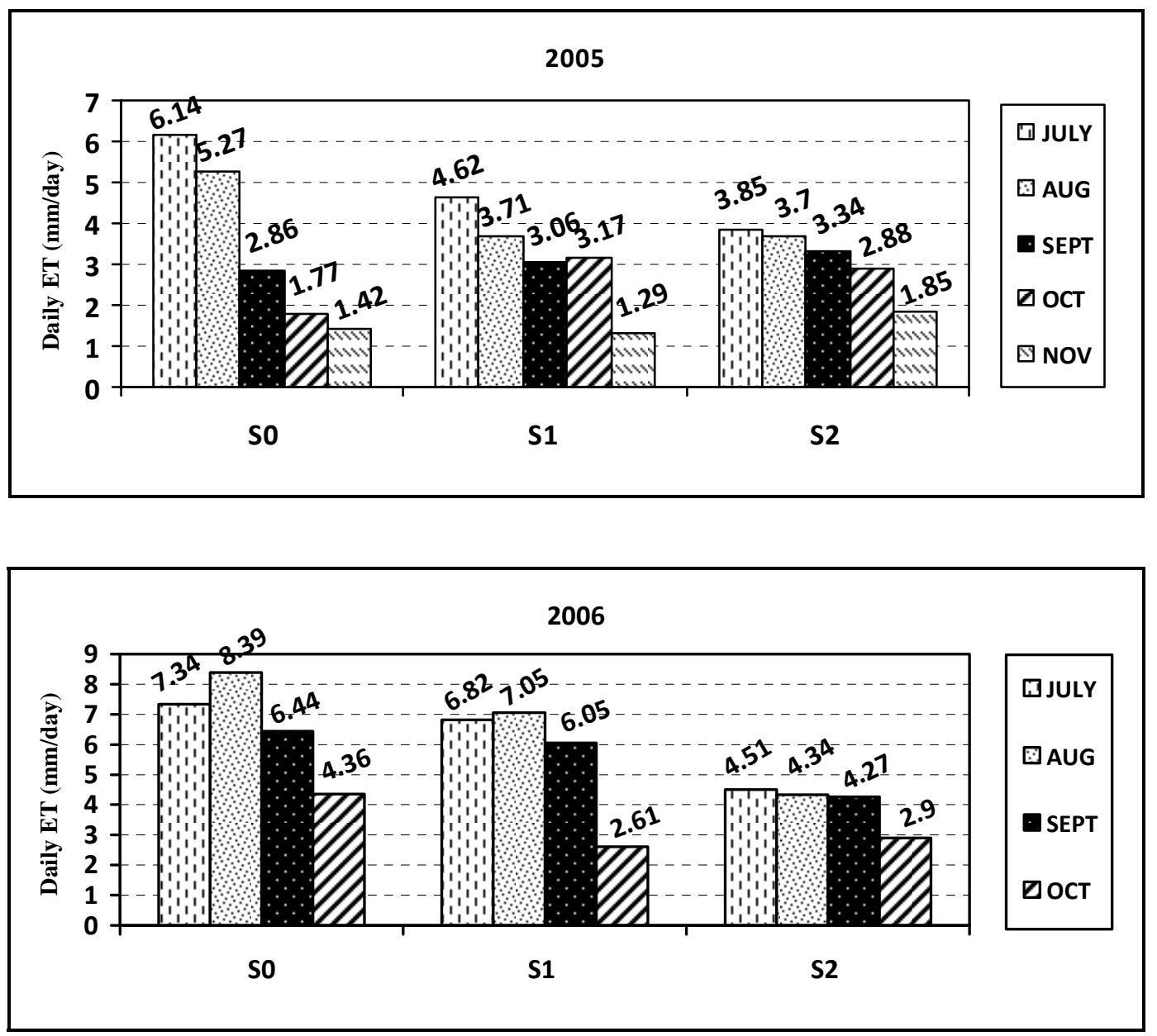

Figure 13. Mean daily ET values ( $\mathrm{mm} /$ day) by month of the Satsuma mandarin trees grafted on Poncirus trifoliata rootstock

\section{DISCUSSION and CONCLUSION}

Results obtained from the study are stated below:

Seasonal and daily evapotranspiration values of the Satsuma mandarin trees grafted on Troyer citrange and Poncirus trifoliata rootstocks were found. Accordingly, of the trees grafted on Troyer citrange and Poncirus trifoliata rootstocks, the highest seasonal evapotranspiration was at the salinity level of S0 $(0.65$ $\mathrm{dS} / \mathrm{m}$ ) while the lowest seasonal evapotranspiration was at the salinity level of $\mathrm{S} 2(6.5 \mathrm{dS} / \mathrm{m})$. However, at the salinity level of $\mathrm{S} 1(3.5 \mathrm{dS} / \mathrm{m})$, evapotranspiration was found to be between the highest and the lowest levels. The evapotranspiration of the Satsuma mandarin trees decreased depending on the increase in the salinity level of irrigation water.

In the study, compared to the mandarin trees grafted on Troyer citrange rootstock, those grafted on Poncirus trifoliata rootstock had a higher evapotranspiration in all subjects. While the evapotranspiration values of the mandarin trees grafted on Troyer citrange rootstock decreased sharply in S1 and S2, decrease in the evapotranspiration values of the mandarin trees grafted on Poncirus trifoliata rootstock was gradual.

The values obtained by Yang et al (2003), Fares and Alva (2000), and Mercül (1987) in their studies on citrus are given in Table 2. The said studies used fresh water so as to find the mean daily evapotranspiration by month; their results are in conformity with the 2005 data of the present study. The data of 2006 increased depending on the amount of irrigation water. The study conducted by Yang et al. (2003) analyzed the short-term (2-month) evapotranspiration of the citrus trees irrigated with a salinity level of $3.8 \mathrm{dS} / \mathrm{m}$. The results obtained were higher than those of the present study. The reason may be that the trees used in the study had been irrigated with saline water since 1996. 
Table 2. Mean daily evapotranspiration values ( $\mathrm{mm} /$ day) of citrus by month according to different studies

\begin{tabular}{|l|c|c|c|c|}
\hline \multirow{2}{*}{ Citrus } & \multicolumn{3}{|c|}{ Fresh Water } & $\mathbf{3 . 8} \mathbf{~ d S} / \mathbf{m}$ \\
\cline { 2 - 5 } & Fares & Yang & Mercül & Yang \\
\hline July & 4.5 & 4.9 & 5.07 & 5.7 \\
\hline August & 5 & 4.3 & 4.56 & 5.15 \\
\hline Semtember & 4 & 4.07 & 3.08 & 4.01 \\
\hline October & 3 & 2.9 & 1.17 & \\
\hline November & 2 & 2.29 & & \\
\hline
\end{tabular}

The information required for scheduling irrigation under saline conditions is evapotranspiration values. However, in literature, many of the studies intended to determine the evapotranspiration of citrus trees used high-quality water. So, for a solution, it is not enough to use such information in the regions where salinity problems are encountered. Therefore, it is possible to use the results of this research, where different salinity levels of irrigation water were

\section{REFERENCES}

Aegean Exporters Association, 2002. 2000/01-2001/02 Period Turkish Citrus Fruit Export Statistical Report, İzmir.

Bear, J., Cheng, D., Sorek, S., Ouazar, D., Herrera, I, 1999. Seawater Intrusion in Coastal Aquifers-Concepts, Methods and Practices. Kluwer, Dordrecht.

Can, B.A., 2004. A Research on Mandarin Production and Marketing in a Selected Group of Enterprises in Seferihisar District of İzmir Province, M.Sc. Thesis, $151 \mathrm{p}$.

Davies, F.S., Albrigo, L.G., 1994. Citrus, Crop Production Science in Horticulture, Cambridge, 254 p.

FAO, 2011. Subject : tangerine production http://faostat.fao.org/site/535/DesktopDefault.aspx?PageID=53 5\#ancor Access: November 2013

FAO, Irrigation and drainage paper 48, 1992. The use of saline waters for crop production, Roma.

Fares, A., Alva, A.K., 2000. Soil water components based on capacitance probes in a sandy soil, Soil Science Society American Journal, 64: 311-318.

Kanber, R., Steduto, P., 1999. Experimental Methodologies for Determining Evapotranspiration. Reviews and Revisions, Adana, $211 \mathrm{p}$. applied, for scheduling irrigation in the regions having the said problem.

It is suggested to inform the producers who have to grow Satsuma mandarin under salinity conditions for some reasons about the advantages of drip irrigation under salinity conditions and the irrigation schedules under such conditions.

In case of drip irrigation, it is possible to determine irrigation water by employing FAO-24 Pan Evaporation Method. It is advisable to perform irrigation at frequent intervals for the purpose of minimizing the damage resulting from salt-related osmotic pressure.

\section{ACKNOWLEDGEMENTS}

We would like to express our gratitude to the Commission of Scientific Research Projects of Ege University (Project No: 2005-ZRF-024) for funding this study.

Kass, A., Gavrieli, I., Yechieli, Y., Vengosh, A., Starisky, A., 2005. The impact of freshwater and wastewater irrigation on the chemistry of shallow groundwater: a case study from the Israeli Coastal Aquifer, Journal of Hydrology, 300, 314-331.

Kutilek, M., Nielsen, D.R., 1994. Soil Hydrology, Cremlingen, Germany, 370 p.

Mercül, A., 1987, A Research on the Evapotranspiration and Irrigation Water Requirement of Citrus Fruits, M.Sc. Thesis, 32 p. Bornova-İzmir.

Storey, R., Walker, R.R., 1999. Citrus and salinity, Scientia Horticulturae, 78, 39-81.

Turkish Statistical Institute, 2012. http://tuikapp.tuik.gov.tr/bitkiselapp/bitkisel.zulA Access: November 2013

Yang, L.S., Yano, T., Aydın, M., Kitamura, Y., Takeuchi, S., 2002. Short term effects of saline irrigation on evapotranspiration from lysimeter-grown citrus trees, Agricultural Water Management, 56, 131-141

Yang, L.S., Takeuchi, S., Yano, T., Kitamura, Y., 2003. Evapotranspiration from citrus trees growing in sandy soil under drip irrigation with saline water, Science China Series D-Earth Sciences 45: 41-46 